\title{
Video as a didactic resource in a hybrid learning environment
}

\section{El video como recurso didáctico en un ambiente de apredizaje híbrido}

HERNÁNDEZ-BÁEZ, Irma Yazmín†๋*, NIETO-YÁÑEZ, Alma Delia, LÓPEZ-DÍAZ, Roberto Enrique and LEÓN-SOSA, Sandra Elizabeth

Universidad Politécnica del Estado de Morelos

ID $1^{\text {st }}$ Author: Irma Yazmín, Hernández-Báez / ORC ID: 0000-0002-3078-9618, CVU CONACYT ID: 212658

ID $1^{\text {st }}$ Coauthor: Alma Delia, Nieto-Yáñez / ORC ID: 0000-0001-8554-8152, CVU CONACYT ID: 212730

ID $2^{\text {nd }}$ Coauthor: Roberto Enrique, López-Díaz / ORC ID: 0000-0003-1716-6704, CVU CONACYT ID: 212691

ID $3^{\text {rd }}$ Coauthor: Sandra Elizabeth, León-Sosa / ORC ID: 0000-0002-6047-4713, CVU CONACYT ID: 648491

DOI: $10.35429 /$ JOTE.2021.15.5.1.6

Received July 10, 2021; Accepted December 30, 2021

\begin{abstract}
The teaching-learning process had a drastic change with the pandemic, first it changed from face-toface to virtual and later it changed to a hybrid modality. In the case of the Universidad Politécnica del Estado de Morelos, the hybrid modality consists of synchronous sessions with students in the classroom and online, this increases the complexity of the design of the appropriate learning environment. The objective of this research was to obtain information that would allow us to see if the use of video as an educational resource has a positive impact on the teaching-learning process in current days. To verify this, the methodology used consisted of five stages: Selection of technological tools, design of the action process using video for each of the four spaces of a hybrid learning environment, execution of the action process, answering surveys and analysis of results. With this study, it was possible to provide teachers with a strategy that allows them to expand their personal toolbox during the teaching-learning process in hybrid environments.
\end{abstract}

Educational video, Hybrid learning environment, Spaces of learning environments

\begin{abstract}
Resumen
El proceso de enseñanza-aprendizaje tuvo un cambio drástico con la pandemia, primero cambió de presencial a virtual y posteriormente cambió a una modalidad híbrida. En el caso de la Universidad Politécnica del Estado de Morelos, la modalidad híbrida consiste en sesiones sincrónicas con estudiantes en el aula y en línea, esto aumenta la complejidad del diseño del entorno de aprendizaje adecuado. El objetivo de esta investigación fue obtener información que permitera visualizar si el empleo del video como recurso educativo tiene un impacto positivo en el proceso enseñanzaaprendizaje en esta nueva normalidad. Para verificar esto, la metodología empleada consistió en cinco etapas: Selección de herramientas tecnológicas, diseño del proceso de acción usando el video para cada uno de los cuatro espacios de un ambiente de aprendizaje híbrido, ejecución del proceso de acción, aplicación de encuestas y análisis de resultados. Con este estudio se logró proporcionar a los docentes una estrategia que permita ampliar su caja de herramientas personal durante el proceso enseñanza-aprendizaje en ambientes híbridos.
\end{abstract}

Video educativo, Ambiente de aprendizaje híbrido, Espacios de los ambientes de aprendizaje

Citation: HERNÁNDEZ-BÁEZ, Irma Yazmín, NIETO-YÁÑEZ, Alma Delia, LÓPEZ-DÍAZ, Roberto Enrique and LEÓNSOSA, Sandra Elizabeth. Video as a didactic resource in a hybrid learning environment. Journal of Technical Education. 2021, 5-15: 1-6

\footnotetext{
* Correspondence to Author (e-mail: ihernandez@ upemor.edu.mx)

$\dagger$ Researcher contributing first author.
} 


\section{Introduction}

Due to the pandemic, there has been a change in the way of teaching-learning, from one day to the next, classrooms had to be abandoned, changing them for virtual classrooms. And now in the current days, education takes a turn again and it was necessary to use a hybrid environment. It should be noted that each institution understands by hybrid education, different combinations of activities, among which the following can be highlighted:

a. Online courses with face-to-face
sessions,
Classroom programs with digital
supports,
Online periods combined with face-to-
face periods,
d. Some online courses and other face-to-
face courses or
e. Synchronous sessions with students in
the classroom and online.

In the case of the Universidad Politécnica del Estado de Morelos (Upemor), the hybrid modality that is being applied is precisely the last one mentioned: Synchronous sessions with students in the classroom and online. What makes the design of a Virtual Learning Environment (VLE) complex is that it needs to allow interaction and attention, by the teacher, to both types of students (face-to-face and virtual) at the same time, providing the same quality of learning, attention and support from the teacher.

According to (Rincón, 2008) in order to incorporate VLE, it is necessary to change the process of acquisition and transformation of knowledge. The integration of meaningful learning activities and taking advantage of the tools that these offer in virtual environments is what is required for the relevance, quality and educational usefulness to be achieved. For all this, it is important to redesign to adapt didactic planning to technological changes, through the construction of a pedagogical and methodological structure, which must be based on content, evaluation and experiences.

On the other hand, depending on their use, Information and Communication Technologies (ICT), can be a source of innovation for teaching, contributing to learning, offering methodologies and resources for the 21st century (Sánchez, 2003).
In hybrid classes, the teacher and the student must incorporate the use of ICT as a didactic resource in the teaching-learning process and as it is proposed in en (Chaupart, 2002) "what is sought is not to create a technological dependence, since ICTs are a means to apply the new, more effective pedagogies for the student".

Today, practically all teachers combine multimedia resources, in one way or another, in their routine within hybrid environments. One of the increasingly common ways of introducing technology into classes is through the use of videos. The projection of multimedia resources offers various advantages to teachers when it comes to transmitting knowledge in a closer and more realistic way, as well as some advantages to students, since they are predisposed to absorb knowledge from this medium.

On the other hand, it has been observed that in the design of a learning environment the way in which the different pedagogical-didactic elements are presented is substantial to achieve a positive predisposition of students to learning. This refers to the relationships that the learning environment fosters among students, among students, materials, and activities, and among students with the environment itself, including teachers.

According to (Chan-Núñez, 2004), the spaces that define the communicative structure of a learning environment are:

a. Information space. Space where the teacher must organize all the information that will be provided to the students.

b. Interaction space. In this space, the teacher must design all the activities that the student must carry out to access the information provided to integrate it into their cognitive structure.

c. Production space. In this space the teacher must design a series of activities that allow students to put into practice what they have learned in the previous space.

d. Display space. In this space, the teacher must design activities that allow showing the results of the training process to all participants, promoting feedback. 
For all the above, it can be seen that integrating video as an educational resource in a hybrid learning environment is not a simple task, but rather that the teacher must have knowledge of the structure of a learning environment, together with digital skills to produce your own videos or select existing videos in such a way that they have a positive impact on your students' learning

The objective of this research is to obtain information that allow to visualize whether the use of video as an educational resource in the four spaces that define the communicative structure of a hybrid learning environment has a positive impact on the teaching-learning process in current days.

Based on the objective, the following research questions were posed:

- How can the educational video be integrated into the four spaces that make up the structure of a hybrid learning environment?

- Will the use of educational video increase student motivation?

- What free-use technological tools can be used to produce quality educational videos?

- What action process should be used to successfully include the use of educational video in the teaching of undergraduate level content in a synchronous hybrid learning environment?

This project was developed at Upemor, taking as a reference two groups of third year (seventh four-month period) of the educational program Ingeniería en Tecnologías de la Información. The work is pertinent because the use of ICTs seeks to improve the performance of the students and consequently the increase of knowledge and skills acquired during the course. The main contribution of this study is to provide teachers with a strategy that allows them to expand their personal toolbox during the teaching-learning process in hybrid environments

This article is organized in five sections: Introduction, methodology, results, conclusions and references.

\section{Methodology}

According to (Álvarez \& Álvarez, 2014), the method of research-action begins with a collective or group idea that some type of improvement or change is desired in the process that is being participated, such is the case of the teaching-learning process. In (Pérez, 1989), the method (research-action) requires the participation of groups, integrating both participants and observers into the inquiry and dialogue process. This method consists of the following steps:

1. Delimitation of the problem to be investigated in action.

2. Plannig the action process.

3. Execution of the action.

4. Evaluation of what is generated in the action.

This set of four steps can be repeated in successive spirals. For the methodology of this work, this research method is taken as a basis, which can be seen in Figure 1.

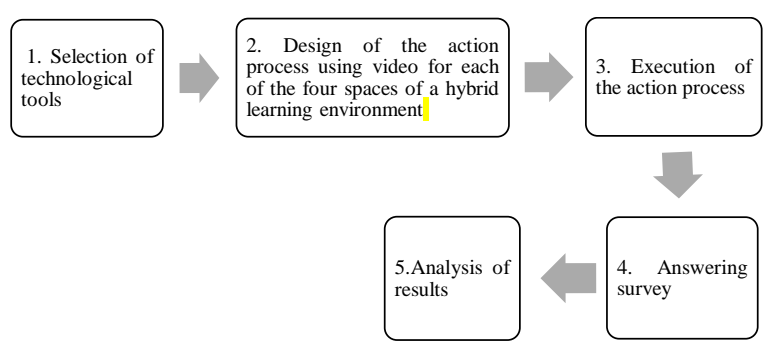

Figure 1 Methodology of work

Source: Own Elaboration

The methodology is made up of five stages:

1. Selection of technological tools. In this stage, a documentary research was carried out to identify the different free access technological tools for the preparation, editing, adaptation and publication of educational videos, which could be used in the design of the action process and which were relevant to each of the four spaces of learning environments.

After an extensive search and testing of various tools, the most appropriate for this research were finally selected. In Table 1 , all the tools used are shown, the space for which each one was used is included, as well as a brief explanation of its use. 


\begin{tabular}{|c|c|c|}
\hline Tool Name & Description & Space \\
\hline $\begin{array}{l}\text { Screencastify } \\
\text { Screencast-o- } \\
\text { matic }\end{array}$ & $\begin{array}{l}\text { The teacher can create } \\
\text { their own videos to } \\
\text { provide information to } \\
\text { their students. }\end{array}$ & $\begin{array}{l}\text { Information } \\
\text { Space }\end{array}$ \\
\hline YouTube & $\begin{array}{l}\text { The teacher can become a } \\
\text { curator of audiovisual } \\
\text { content, to later share } \\
\text { them with their students in } \\
\text { the information space. }\end{array}$ & $\begin{array}{l}\text { Information } \\
\text { Space }\end{array}$ \\
\hline $\begin{array}{l}\text { Edpuzzle } \\
\text { Deck.toys }\end{array}$ & $\begin{array}{l}\text { The teacher can modify } \\
\text { their own videos or third- } \\
\text { party videos, making them } \\
\text { interactive, incorporating } \\
\text { questions and / or } \\
\text { activities that allow the } \\
\text { student to interact with the } \\
\text { material. }\end{array}$ & $\begin{array}{l}\text { Interaction } \\
\text { Space }\end{array}$ \\
\hline $\begin{array}{l}\text { Screencastify } \\
\text { Screencast-o- } \\
\text { matic } \\
\text { Flipgrid }\end{array}$ & $\begin{array}{l}\text { The student can use these } \\
\text { tools to produce their own } \\
\text { videos in which they put } \\
\text { into practice what they } \\
\text { have learned in the } \\
\text { interaction space. }\end{array}$ & $\begin{array}{l}\text { Production } \\
\text { Space }\end{array}$ \\
\hline $\begin{array}{l}\text { Flipgrid } \\
\text { Padlet }\end{array}$ & $\begin{array}{l}\text { Through these tools, } \\
\text { students can publish their } \\
\text { videos and receive } \\
\text { feedback from their } \\
\text { classmates and teacher. }\end{array}$ & $\begin{array}{l}\text { Display } \\
\text { Space }\end{array}$ \\
\hline
\end{tabular}

Table 1 Selected technological tools Source: Own Elaboration

\section{Design of the action process using} video for each of the four spaces of a hybrid learning environment. The course was designed incorporating video as an educational resource. It should be noted that the university where this proposal was applied uses Google Classroom as an LMS platform, combined with synchronous classes through Google Meet. Consequently, the entire elaborated design relies on these two platforms. The following describes how the video was included in each of the spaces of the learning environment.

Information space: For this space, several multimedia digital resources were designed in video format, through which, the basic information about topics of the learning unit, were presented to students. For the elaboration of the videos, the following were used: Screencastify y Screencast-o-matic. Several public videos on YouTube were selected too.
Interaction space: Para For this space, a set of activities was designed that would allow students to interact with the multimedia digital resources designed in the previous space. For the development of these activities, videos were used, to which interactivity elements were included, such as questions (open, multiple-choice, false and true). In this case, for the design of this type of activities, the Edpuzzle tool was used. In addition, videos were made more dynamic using the Deck.toys tool, which allows mixing videos with recreational activities on an interactive board that promotes student interaction with videographic materials in greater depth and breadth. The aforementioned tool provides elements that allow formative evaluation, providing the teacher with a report of the progress and achievements of their students, so that the teacher, at a later time, can provide feedback and guide the students in their learning process, accommodating error and its systematic correction without quantitative penalization.

Production space: For this space, a series of activities were designed to allow students to put what they learned into practice, with the intention of generating the necessary evidence for evaluation and qualification. The development of a project from the situational approach was proposed that would allow the teacher to evaluate the achievement of the expected learning results. As part of the evidence generated by the students, a video was requested explaining and defending the project developed. For the elaboration of the video, the students used Screencastify, Screencast-omatic, Flipgrid or Powtoon.

Display space: Finally, the students were asked to share the video produced in the previous space on a Padlet board, allowing interaction through reactions and / or comments from all the students in the group. Thus, the students were able to receive feedback, criticism, and comments from their peers, as well as from the course teacher. Fostering an environment of socialization and feedback. It should be noted that the tools and resources used throughout the four spaces allow students an asynchronous interaction, being totally relevant for the hybrid modality, since the students do not necessarily have to be present and active during class to be able to interact with the materials, resources and / or their mates.

HERNÁNDEZ-BÁEZ, Irma Yazmín, NIETO-YÁÑEZ, Alma Delia, LÓPEZ-DÍAZ, Roberto Enrique and LEÓN-SOSA, Sandra Elizabeth. Video as a didactic resource in a hybrid learning environment. Journal of Technical Education. 2021 
Once all the audiovisual resources and activities had been designed and prepared, the action process was designed, which is shown in Table 2.

\begin{tabular}{|c|c|c|c|}
\hline \# & Activity & $\begin{array}{c}\text { Supervision } \\
\text { activity }\end{array}$ & Duration \\
\hline 1 & $\begin{array}{l}\text { At the beginning of the } \\
\text { learning unit, in the first } \\
\text { session, the structure into } \\
\text { which the learning } \\
\text { environment is divided is } \\
\text { presented to students, } \\
\text { detailing and explaining the } \\
\text { elements that compose it: } \\
\text { the four spaces. In addition, } \\
\text { they are informed where the } \\
\text { lesson plan for each session } \\
\text { included in the learning unit } \\
\text { will be published. The } \\
\text { objective of the unit is } \\
\text { presented and a short } \\
\text { framing session is held. The } \\
\text { student is allowed to } \\
\text { interact with the learning } \\
\text { environment, with the aim } \\
\text { of becoming familiar with, } \\
\text { experimenting and asking } \\
\text { questions to resolve doubts } \\
\text { about it. }\end{array}$ & $\begin{array}{l}\text { Information is } \\
\text { collected } \\
\text { through } \\
\text { observation: } \\
\text { student } \\
\text { behavior, } \\
\text { interest in the } \\
\text { learning } \\
\text { environment, } \\
\text { questions and } \\
\text { doubts raised. }\end{array}$ & $1 \mathrm{hr}$ \\
\hline 2 & $\begin{array}{l}\text { A series of sessions is } \\
\text { programmed in which the } \\
\text { student is asked to interact } \\
\text { with the different elements } \\
\text { of the learning space, for } \\
\text { each session, in advance, } \\
\text { the class plan is published, } \\
\text { in such a way that, if a } \\
\text { student loses their } \\
\text { connection or have a } \\
\text { technical problem to join } \\
\text { the synchronous video call, } \\
\text { he or she, can have access } \\
\text { to the instructions, materials } \\
\text { and activities that must be } \\
\text { carried out during the } \\
\text { session. } \\
\text { The teacher acts as a } \\
\text { facilitator and supporter in } \\
\text { each of these synchronous } \\
\text { sessions. }\end{array}$ & $\begin{array}{l}\text { Information is } \\
\text { collected } \\
\text { through } \\
\text { observation: } \\
\text { behavior, } \\
\text { interest, doubts. } \\
\text { The results of } \\
\text { the activities } \\
\text { carried out by } \\
\text { the students are } \\
\text { collected in the } \\
\text { spaces interaction and } \\
\text { production. }\end{array}$ & $\begin{array}{l}\text { Various } \\
\text { sessions } \\
\text { of } 3 \text { hours } \\
\text { each. }\end{array}$ \\
\hline 3 & $\begin{array}{l}\text { An evaluation session is } \\
\text { scheduled through the } \\
\text { display space, promoting } \\
\text { student interaction by } \\
\text { providing feedback from the } \\
\text { teacher. }\end{array}$ & $\begin{array}{l}\text { The results of } \\
\text { the product } \\
\text { evidence (video) } \\
\text { prepared by the } \\
\text { students are } \\
\text { collected. } \\
\text { Information } \\
\text { about level of } \\
\text { socialization and } \\
\text { interaction } \\
\text { among students } \\
\text { is collected. }\end{array}$ & $2 \mathrm{hrs}$ \\
\hline 4 & $\begin{array}{l}\text { A survey is applied to the } \\
\text { students, for this an ad hoc } \\
\text { questionnaire is used. The } \\
\text { above in order to collect the } \\
\text { impressions of the students } \\
\text { after participating in the } \\
\text { experience. }\end{array}$ & $\begin{array}{l}\text { Surveys results } \\
\text { are collected. }\end{array}$ & $\begin{array}{l}30 \\
\text { minutes }\end{array}$ \\
\hline
\end{tabular}

Table 2 Action process

Source: Own Elaboration
3. Execution of the action process. At this stage of the research, the study group was defined, determining that the experimentation would be carried out with two groups of third year (seventh four-month period) of the educational program of Ingeniería en Tecnologías de la Información of the Universidad Politécnica del Estado de Morelos. The subject where the action process was applied was Formulation of Projects of Information Technology.

The study group has the following characteristics: they are groups of around 30 students each, made up mostly of men, the students take their classes in a hybrid format, that is, half of the group attends the institution in person and rest are connected to the class through a video call, the classes are synchronous, although it were designed to support that a student can follow the class, access the instructions, materials and activities also asynchronously, even through the different tools used, students can interact with each other and the teacher asynchronously. Students rotate their attendance each week of class, so that all students can experience attending class sessions in person and virtually.

The proposed action process was put into practice only for one learning unit of the subject.

4. Answering survey. Once the students' experience of the designed proposal was concluded, a survey was applied, for this purpose an ad hoc questionnaire was designed, which follows a Likert scale (Fabila, Minami, \& Izquierdo, 2012). The survey was divided into two sections: the first containing closed questions to assess the student's perception of their learning using the experience of incorporating video as a didactic resource in a hybrid learning environment and the second part, open questions to collect general comments from students.

5. Analysis of results. In the last stage, the analysis of all the results obtained during the investigation was carried out. 


\section{Results}

The questionnaire applied to the students consisted of seven questions, five open questions on a Likert-type scale about the learning experience lived by the students, and two open questions with the aim of recovering perceptions and general comments about the activity. In Table 3, the descriptive statistics of the application of the instrument are presented.

Of all the questions asked, question $\mathrm{CO} 3$ with a mean score of 4.90 , can be seen as the result with the highest number of adhesions, followed by questions $\mathrm{CO} 2$ and $\mathrm{CO} 4$ with a mean of 4.81. From what seems clear, that students recognize that the combination of technological tools, educational resources (videos) and class design were appropriate and, in the particular case of the use of videos, they even recognize that they contributed to their learning. In contrast, questions $\mathrm{CO}$ and $\mathrm{CO5}$, obtained a slightly lower average 4.63 and 4.65 , respectively, both questions are specifically focused on the level of learning obtained. These results were reinforced in the answers to the open questions, below, some answers that the students gave to the question are transcribed:

Question A01. What aspects of this learning unit do you consider to have been the most useful or valuable?: "The activities, dynamics and feedback from the teacher in our work ", " the way of working ", "... every time she leaves us an activity, she gives us the necessary material or resources to be able to do a job well done ", " the dynamic process... it is very good, since we not only base ourselves on theory, we carry out team activities and make us express our ideas ", "... we are always provided support videos, in case we have doubts, which makes the topics more interesting ... ", “... The material (videos) provided... ", “" the class materials ". In general, students recognize that video as a teaching resource is one of the most useful or valuable elements.

Finally, some comments made by the students in the question A02 are transcribed. A02. Write your general comments regarding this learning unit: "I am the most distracted person in the world, I NEED dynamic activities to keep my attention and this is the first class where I don't get distracted all the time ... "," the teacher produces excellent teaching material". In general, all student comments were positive or neutral.
In addition to the instrument, data was collected throughout the action process, through direct observation, highlighting the following:

1. The level of student participation in the different activities increased during the learning unit. Group motivation increased.

2. The general average obtained in the evaluation of the partial of the subject, improved with respect to groups that took the same subject in previous years.

3. In general, the students' comments have been very positive regarding the technique and tools used by the teacher.

\begin{tabular}{|c|c|c|c|c|c|}
\hline \# & Question & $\mathbf{N}$ & $\begin{array}{c}\text { Mea } \\
\text { n }\end{array}$ & $\begin{array}{l}\text { Typ. } \\
\text { Desv. }\end{array}$ & $\begin{array}{l}\text { Stan. } \\
\text { Error } \\
\text { of the } \\
\text { mean }\end{array}$ \\
\hline & Closed questions & & & & \\
\hline $\mathrm{C} 01$ & $\begin{array}{l}\text { Did the activities } \\
\text { developed during the } \\
\text { unit help you to } \\
\text { facilitate your } \\
\text { learning? }\end{array}$ & 48 & 4.63 & 0.53 & 0.08 \\
\hline $\mathrm{C} 02$ & $\begin{array}{l}\text { Do you consider that } \\
\text { the didactic material } \\
\text { and audiovisual } \\
\text { educational resources } \\
\text { provided in this unit } \\
\text { contributed to your } \\
\text { learning? }\end{array}$ & 48 & 4.81 & 0.45 & 0.06 \\
\hline $\mathrm{C} 03$ & $\begin{array}{l}\text { Do you consider that } \\
\text { the technological } \\
\text { tools used in this } \\
\text { learning unit were } \\
\text { adequate? }\end{array}$ & 48 & 4.90 & 0.31 & 0.04 \\
\hline $\mathrm{C} 04$ & $\begin{array}{l}\text { Do you consider that } \\
\text { the dynamics / design } \\
\text { of the class allows the } \\
\text { adequate participation } \\
\text { of both face-to-face } \\
\text { and virtual students? }\end{array}$ & 48 & 4.81 & 0.45 & 0.06 \\
\hline $\mathrm{C} 05$ & $\begin{array}{l}\text { Do you consider that } \\
\text { you have acquired the } \\
\text { ability to elaborate a } \\
\text { value proposition } \\
\text { canvas? }\end{array}$ & 48 & 4.65 & 0.56 & 0.08 \\
\hline & \multirow{2}{*}{\multicolumn{5}{|c|}{$\begin{array}{l}\text { Open questions } \\
\text { What aspects of this learning unit do you think } \\
\text { have been the most useful or valuable? }\end{array}$}} \\
\hline $\mathrm{A} 01$ & & & & & \\
\hline A02 & \multicolumn{5}{|c|}{$\begin{array}{l}\text { Write your general comments regarding this } \\
\text { learning unit }\end{array}$} \\
\hline
\end{tabular}

Table 3 Descriptive statistics Source: Own Elaboration

HERNÁNDEZ-BÁEZ, Irma Yazmín, NIETO-YÁÑEZ, Alma Delia, LÓPEZ-DÍAZ, Roberto Enrique and LEÓN-SOSA, Sandra Elizabeth. Video as a didactic resource in a hybrid learning environment. Journal of Technical Education. 2021 


\section{Conclusions}

University students are digital natives so the use of technological tools as didactic tools is widely recommended. And the use of video as an educational resource was a positive addition to the hybrid class, which allowed students with poor or no connectivity during synchronous class sessions to have access to the class, the material and the activities of the unit. learning, allowing you to go at your own pace and adapting to your personal schedules.

This type of tool also supported motivation, which according to (Peinado \& Navarro, 2014) it is an important element in any work methodology, including the educational field, as it guarantees the effectiveness and efficiency in the use of technology in the teaching-learning process.

It should also be noted that although the strategy proposed in this research was successful, it takes a long time to prepare and design each of the class sessions, in addition to requiring extensive training in the use of technologies and teaching strategies applied. In addition to the fact that the teaching of the class to students who take it in person, requires the use of a computer laboratory during all sessions, so the use of this type of designs would be complicated in subjects that do not have a laboratory in all his classes.

Finally, as future work, it is proposed to apply the proposed action process to the entire subject and not just to a learning unit. In addition to seeing the possibility of replicating this design in more subjects, particularly those that are considered complex, due to the high failure rate they report, such as those related to programming or basic sciences. The above, in order to see if it is possible to replicate in this type of subject, the good results obtained in this pilot test.

\section{References}

Chan-Núñez, M. E. (10 de noviembre de 2004). Tendencias en el diseño educativo para entornos de aprendizaje digitales. Revista Digital Universitaria, 5(10), 1-26.

Chaupart, J. (2002). Las Nuevas Tecnologías de la Información y de la Comunicación y su Uso en Educación. NTIC y Educación.
Álvarez, A., \& Álvarez, V. (2014). Métodos en la investigación educativa. México: Horizontes educativos.

Barraza-Macías, A., \& Barraza-Navarez, S. (2019). Procrastinación y estrés. Análisis de su relación en alumnos de educación media superior. Revista Investigación Educativa.

Fabila, A., Minami, H., \& Izquierdo, M. (2012). La Escala de Likert en la evaluación docente: acercamiento a sus características y principios metodológicos. Perspectivas docentes, 31-40.

Martinez, H., Esmeralda, L., Cantu, R., \& Patricia, S. (2018). Tutoriales como apoyo en el aprendizaje del estudiante en el área de administración. 710-715.

Peinado, P., \& Navarro, D. (2014). Aumento de la motivación mediante el uso de redes sociales. Didáctica, innovación y multimedia, 1-15.

Pérez, A. (1989). Paradigmas contemporáneos de investigación didácticas. En J. Gimeno, \& A. Pérez, La enseñanza: su teoría y su práctica (pág. 18).

Rincón, M. (2008). Los entornos virtuales como herramienta de asesoría académica en la modalidad a distancia. Revista Virtual Universidad Católica del Norte(25).

Sánchez, J. (2003). Integración Curricular de TICs Concepto y Modelos. Revista Enfoques Educacionales, 5(1), 51-56. 